\title{
sciendo

\section{Environmental and Climate Dilemma: Coal for Heating or Clean Air for Breathing: A Case of Prishtina}

\author{
Bujar BAJCINOVCI* \\ Faculty of Civil Engineering and Architecture, University of Prishtina, Prishtina, 10000, Kosovo
}

\begin{abstract}
Air pollution as a global issue is an essential health problem, faced by millions of people all over the world. It is a huge problem encountered by the citizens of the city of Prishtina, too. The benefit from the cheapest forms of energy, that generated from coal-fired power plants, and the one derived from the low financial cost, raises the question: do we have to compensate this energy with our health? This paper presents the analysis of the emanations, such are coal-fired power plants in the vicinity of the city of Prishtina, and aims to determine the accepted level and health framework boundaries for coal-fired power plants and coal processing activities. The research methods consist of empirical observations and data analysis on health degradation, environmental and greenhouse gas contribution to the climate change. The actual state of energy production is not the most effective pathway to the stability of basic load for energy. Hence, the debate focused around environment tends to fail the essential need for supplying Kosovo with electricity, something for which power plants are suitable. Unfortunately, with all our environmental stubborn beliefs, renewable sources such as sun and wind are not, in the present efficiency for Kosovo. The present hazardous air quality requires well defined lawful steps and activities. Thus, the research findings recommend and promote precise immediate environmental measures.
\end{abstract}

Keywords - Air pollution; climate; coal; environment; power plants; Prishtina; urban solutions

\section{INTRODUCTION}

Air pollution as a global issue is drastically reflected in urban health conditions, by forming a common contemporary malady syndrome. Surely, air pollution and metabolic syndrome are affecting more or less millions of people all over the world, ergo, among them are the citizens of the city of Pristina, the capital of the Republic of Kosovo. Originally, in the Prishtina region, the air pollution originates from complex and different hazard emanations, such as: the power plants in vicinity of the city of Prishtina, coal-fired power plants, coal used as an energy for heating in residential buildings, and heavy air pollution emanated from the urban traffic. Moreover, the coal production causes emissions of many toxic heavy metals, and subsequently, the coal mining and generation of electricity stimulate the climate change, which further causes air degradation [1]. In Prishtina, high level of pollution is linked to the socio-economic conditions, where most of the citizens use coal for heating because it is considered as a low-cost source of energy. The same source of energy is used on the power plants, Kosovo-A and B. Obviously, there is a crucial environmental and climate dilemma: Do the benefits generated from the cheapest forms of energy, the one generated from coal-

\footnotetext{
* Corresponding author.

E-mail address: bujar.bajcinovci@uni-pr.edu 
fired power plants, and that derived from the low financial cost, have to be compensated with our health? Is there any other solution, an alternative or environmental hope for the citizens of the city of Prishtina, and Kosovo in general? Coal handling and grinding processes are correlated with powerful environment pollution, with the fine dust ejection into the environment. The problem is specifically critical when a coal-fired power plants, and coal processing company are located in a vicinity of massively populated cities, such is the case of Prishtina [2]. Furthermore, air quality is also degraded in those situations when we have to highlight that 30-40\% of citizens regularly use electricity for heating in Kosovo. Although the impact of air pollution is certainly a global health burden [3], and according to the World Health Organization, habitats with heavy degraded air quality are responsible for the death of about 3 million people, annually. Moreover, these phenomena involve all nations globally [4]. In the context of Kosovo, for more than 18-years residents have been living near coalfired power plants, whose production crucially depends on coal processing activities. Furthermore, their lives have been affected by a dust polluted environment, enforced by industrial pollution, noise pollution, and persistent urban resettlements. According to Lillywhite et al., resettlements are multiplex, disruptive, and intrusive actions, indicating that those decisions with good objective in the beginning, could still have bad consequences and worse off for resettled citizens [5]. Kosovo is counted as the fifth country in the world for its reserves of coal, respectively for lignite. According to the 2010 Governmental Strategy of Kosovo, the country has about 12.5 billion metric tons of coal reserves, hence, according to the Hastorun at USGS, Kosovo's confirmed brown coal reserves were estimated to be about 14.7 billion metric tons, considered to be minable [6]. In the period of 2011-2012, there was a paradox situation, where Kosovo had imported about 100000 metric tons of coal, referring to the legal debt issues between the Kosovo Energy Corporation and Kosovo Coal Corporation, which had resulted that coal and wood prices had increased in the market to about $60 \%$. It is estimated that in Kosovo about 1.1 million metric tons of lignite ash are generated and dumped annually in dedicated reservoirs. Furthermore, it is estimated that ash dump of the coal-fired power plant Kosova-A, is about 190 ha, and in the power plant Kosova-B is 200 ha. The open pit ash with large surface area at power plants Kosova-A and Kosova-B has as a consequence a heavy distribution of dust in the air, as well as a contamination of surroundings as well as groundwater. In this ambience, emissions of carbon dioxide, methane, nitrous oxide, and all other substances as paramount greenhouse gases straight annihilate health conditions of the environment, also health hazard are indicated through strong interactions of the above cited contaminants. The inhabitants of the region of Obiliq town, situated in the close vicinity of the power plants, Kosovo-A and B, are medically confirmed to be suffering from respiratory diseases, such as asthma, throat cancer, and lung cancer. The records from the officials of Obiliq show that there are 30-40\% more respiratory illnesses in this town than in other regions of Kosovo. Based on the statistics of the population in Kosovo, it is estimated that we have a health situation, where 835 people died prematurely due to the air pollution, 310 new cases of chronic bronchitis, 600 hospital admis sions, 22900 cases for lung disease in children, and above 11600 emergency cases have been submitted as a consequence of the air pollution [7]. Furthermore, there is a fundamental tie amongst the coal-fired power plants, coal processing companies, and a necessity for the generation of electricity, which is needed a lot in Kosovo [8], [9]. The aim of this paper is to describe the data analysis and statistically comprise the emanations: from coal-fired power plants in the vicinity of the city of Prishtina, coal as the source for heating in residential buildings, and identifying a scope of feasible opportunities to minimize the health degradation from above stated sources of pollution. In addition to that, this study aims to determine the accepted level and health framework boundaries for coal-fired power plants, and coal processing activities. 


\section{RESEARCH METHODS}

The purpose of this research is to find the answer of the benefits from coal-fired power plants, and energy derived with the low financial cost, in relation to the acceptable boundaries for the human health. The research methods are composed of empirical observations on health degradation, statistical data, environmental and greenhouse gas contribution from the Prishtina region. The research has been strengthened with data and material from the literature review, regarding the morphology of the spatial zone, microclimate, pollution from traffic, the temperature inversion, and statistical data. Supplementary research material consists of photos, spreadsheets, tables and figures with a close observation of the main polluters, open pit ash areas, and coal mining activities.

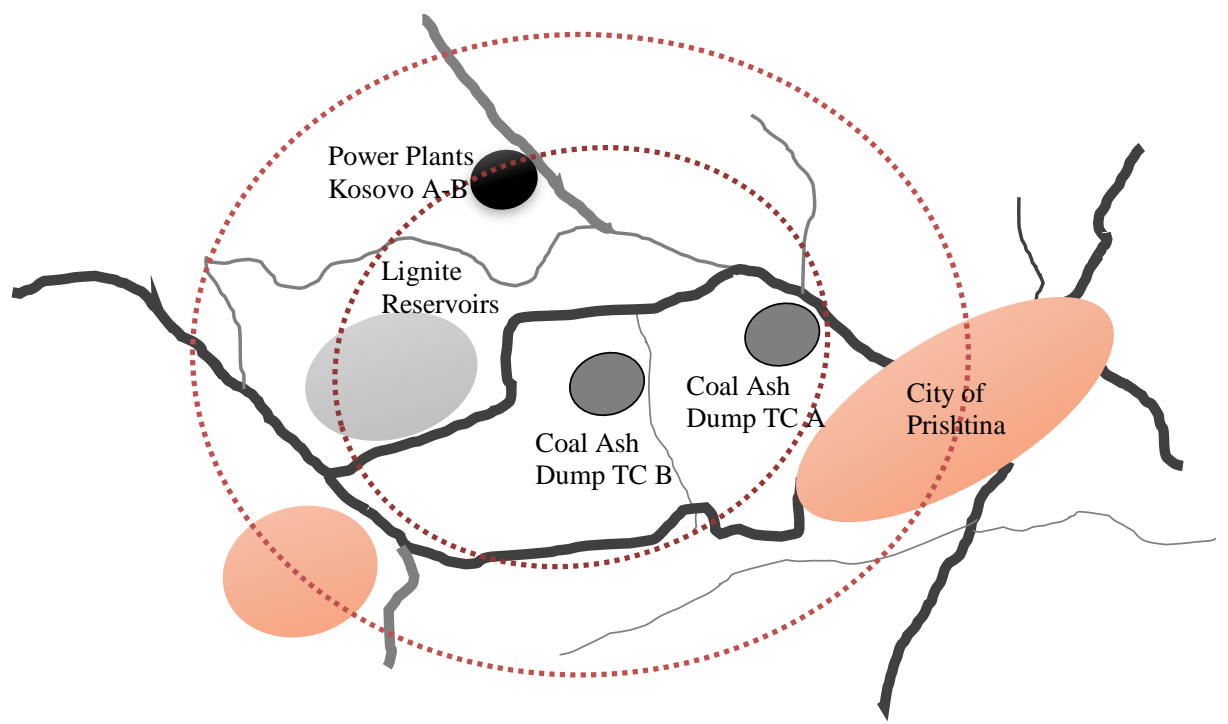

Fig. 1. Spatial relation of Prishtina, Power plants TC A-B, lignite reservoirs, and coal ash dumps.

Energy is crucial and essential for all human activities, especially when the governments apply the efficiency action plan [10]. It provides the desired standard of living, social well-being, and human development. The system with sufficient capacity of sustainable energy is a prerequisite for the development of the entire region. Energy sector in Kosovo is one of the main pillars of supporting economic and human development. Hence, the production of energy is one of the main activities with substantial environmental impact. Laws that correspond to the production of energy and environmental protection in Kosovo aim to regulate and guarantee the right of citizens for supply of electricity, as well as their right to live in a healthy environment with clean air and water. Furthermore, these laws aim to protect the human health, flora and fauna, the natural and cultural heritage of the environment as well. Within the Kosovo Energy Corporation there are two power plants: Kosovo-A and Kosova-B. Power plants are complex energy systems that consist of several technological units, the purpose of which is to transform the energy from natural resources, into thermal and electrical energy. Power plant Kosovo-A is the first power plant built in Kosovo, respectively in Obiliq, located $8 \mathrm{~km}$ from Prishtina. Power plant Kosovo-A consists of five energetic blocks, enumerated as A1, A2, A3, A4 and A5. Working blocks A3, A4 and 
A5 are functional and according to the current production plan they are operational, and usually one of them is in reserve mode due to readiness.

Energetic blocks A1 and A2 are out of service, without defined status, and according to the actual plans they will remain as such until the closing process, expected to be decommissioned altogether with other units. The annual production of the electricity from Power plant Kosovo-A for the fiscal year of 2016 was: 2314 809.15 MWh [11]:

- Working block A1 was released in operation in 1962, with a capacity of 65 MW;

- Working block A2 was released in operation in 1965, with a capacity of $125 \mathrm{MW}$;

- Working block A3 was released in operation in 1970, with a capacity of $200 \mathrm{MW}$;

- Working block A4 was released in operation in 1971, with a capacity of $200 \mathrm{MW}$;

- Working block A5 was released in operation in 1975, with a capacity of $210 \mathrm{MW}$.

Power plant Kosovo-B was built in Obiliq, located $13 \mathrm{~km}$ from Prishtina. Power plant Kosovo-B is the power plant with the largest power generation potential in Kosovo. Power plant Kosovo-B consists of two working blocks, enumerated as B1, B2. The annual production of the electricity from Power plant Kosovo-B for the fiscal year of 2016 was: 3933959 MWh [11]. Both working blocks are in operation. The much-needed investments recently made in this Power plant have significantly improved the operational status of the system:

- Working block B1 was released in operation in 1983, with a capacity of $339 \mathrm{MW}$;

- Working block B2 was released in operation in 1984, with a capacity of 339 MW.

\subsection{Coal Consuming and Emissions from Power Plants: Kosovo A and B}

Power plants Kosovo-A and Kosovo-B, for electricity production use raw materials of coal, respectively lignite during combustion, which energy then consumes water to produce high pressure steam, and required working temperature. Produced vapor then proceeds to the generator, from which the electricity is obtained. Kosovo coal appertains to the lignite type of coal, known also as brown coal. Coal after being excavated with a rotor excavator with a continuous system is transported to the depots of Power Plant Kosovo-A and B. Working sectors are bridged between mines and Power Plants, where coal is crushed in particles, then classified in various fractions, mainly for the trade market. Coal for Power Plants is prepared with granules from $0-30 \mathrm{~mm}$, then those granules through the strips pass into bunkers, from where it goes to the mill for grinding, and continues for the injection into the boiler of Power Plants [11].

Table 1. Monthly Coal Consumption in Power Plant Kosovo-A-B, During 2016 [11]

\begin{tabular}{lllll}
\hline Operation Blocks & $\mathbf{A 3}, \mathbf{A 4}, \mathbf{A 5}$ & B1 & B2 \\
\hline No. & Month & Specific consumption, t/MWh & Specific consumption, t/MWh & Specific consumption, t/MWh \\
\hline 1 & January & 1.476 & 1.3 & 1.20 \\
2 & February & 1.113 & 1.28 & 1.27 \\
3 & March & 1.300 & 1.28 & 1.27 \\
4 & April & 1.349 & 1.26 & 1.26 \\
5 & May & 1.508 & 1.26 & 1.26 \\
6 & June & 1.322 & 1.26 & 1.26 \\
7 & July & 1.903 & 1.25 & 1.25 \\
8 & August & 1.817 & 1.26 & 1.25 \\
9 & September & 1.982 & 1.26 & 1.26 \\
\hline
\end{tabular}




\begin{tabular}{|c|c|c|c|}
\hline Operation Blocks & $\mathrm{A3}, \mathrm{A4}, \mathrm{A5}$ & B1 & B2 \\
\hline No. Month & Specific consumption, $t / \mathbf{M W h}$ & Specific consumption, t/MWh & Specific consumption, $t / M W h$ \\
\hline 10 October & 0.780 & 1.26 & 1.26 \\
\hline 11 November & 1.489 & 1.27 & 1.27 \\
\hline 12 December & 2.093 & 1.33 & 1.25 \\
\hline Total & 1.522 & 1.27 & 1.25 \\
\hline
\end{tabular}

As presented in the Table 1, during 2016, Power Plant Kosovo-A spent 3523360 tons of coal, whereas the average consuming of the Power Plant was about $1.522 \mathrm{t} / \mathrm{MWh}$. While in Power Plant Kosovo-B, during 2016, 4996595 tons of coal were spent, and the average consuming was around $1.26 \mathrm{t} / \mathrm{MWh}$. Total coal consumption for both Power Plants in 2016 was 8519955 tones [11]. The quality of coal is determined by the samples analysed each day in both Kosovo Energy Corporation thermal power plants and laboratories. Emissions of pollutants into the atmosphere are higher than the allowed limit values due to the design of electrostatic filters, non-existence of reduction plants for pollutants, such as: $\mathrm{NO}_{\mathrm{x}}$ and $\mathrm{SO}_{2}$, high content of inorganic materials in brown coal, and other elements during the combustion process. After the installation of new electrostatic filters in the Power Plant Kosovo-A, the operation ensures that particulate emissions are below the foreseen criteria, and according to the Kosovo Energy Corporation, this Power Plant has made a significant environmental improvement. In Power Plant Kosovo-A in A3, A4 and A5 operating blocks, particulate emissions were measured after the equipment for continuous monitoring of dust-particles emissions was installed. Particle emissions and dust material in Power Plant Kosovo-B, due to the design of electrostatic filters are not in compliance with the actual standards of dust emission. In the Power Plant Kosovo-B are installed the analysers for continuous measurements of particle emissions, specifically for the dust. Sulphur dioxide emissions, $\mathrm{SO}_{2}$ are based on the amount of SO on brown coal, as well as by the alkaline features of lignite. In Power Plant Kosovo-A, $\mathrm{SO}_{2}$ emissions are calculated, while in Power Plant Kosovo-B there are analysers for continuous measurements of $\mathrm{SO}_{2}$ [11]. Furthermore, the reason for the emission of $\mathrm{NO}_{\mathrm{x}}$ are the content of nitrogen in lignite in the process for combustion. Emission of $\mathrm{NO}_{\mathrm{x}}$ is caused by the ignited nitrogen which is contained in the brown coal, Nitrogen oxides are formed by the chemical reaction of nitrogen and oxygen freed from the air. Nitrogen oxidation requires a certain value of temperature and a sufficient amount of oxygen. Power Plant Kosovo-A, and $\mathrm{B}$ do not actually use any system to reduce the dissipation of $\mathrm{NO}_{\mathrm{x}}$. At Power Plant Kosovo-A, $\mathrm{NO}_{\mathrm{x}}$ emissions are calculated, while in Power Plant Kosovo-B, emissions are set from the analysers for the continuous measurement of $\mathrm{NO}_{\mathrm{x}}$ emissions. Carbon dioxide is a crucial factor that affects the global warming. $\mathrm{CO}_{2}$ emission is proportional to the carbon content in fuels, and the quality of burned derivatives [11]. Actually, in Power Plants Kosovo-A and B, the best option to reduce their emissions is to increase equipment efficiency and burn fuel more rationally. Carbon dioxide emission at Power Plant Kosovo-A is based on calculations according to lignite quality and strength of blocks based on stoichiometric relationships of chemical reactions, whereas in Power Plant Kosovo-A there are established analysers for the continuous measurement of $\mathrm{CO}_{2}$ emissions. The combustion process is followed by the emission of carbon monoxide. This broadcast causes growth fuel consumption and is an indicator of improper efficiency of the Power Plants. $\mathrm{CO}$ is a consequence of the poor process of combustion, and incomplete burning process. The broadcasting of $\mathrm{CO}$ is measured in Power Plants Kosova-B but it is not measured in the Power Plant Kosova-A! 
Regarding heavy metals, brown coal contains heavy metals and other hazardous materials. Despite small concentrations, they can cause devastation to the environment and human health. Most heavy metals, such as: As, $\mathrm{Cd}, \mathrm{Cr}, \mathrm{Cu}, \mathrm{Hg}, \mathrm{Ni}, \mathrm{Pb}, \mathrm{Se}, \mathrm{Zn}, \mathrm{V}$ are released as compounds of oxides, chlorides. Only $\mathrm{Hg}$ and Se are partially present at the steam phase, [11] Mercury is a heavy metal that causes enormous health problems, related to the emissions from the process of coal combustion. Parts of the lignite mercury are divided into the vapor phase. Most heavy metals are related to the process in the flying ash, at the working temperature of the Power Plant steam turbine.

TABLE 2. Total AND SPECIFIC ANNUAL EMISSIONS OF POWER PlanTs DURING 2016 [11]

\begin{tabular}{|c|c|c|c|c|c|c|c|}
\hline \multirow[t]{2}{*}{ Power Plants } & \multirow{2}{*}{$\begin{array}{l}\text { Production, } \\
\text { MWh }\end{array}$} & \multicolumn{3}{|l|}{ Dust } & \multicolumn{3}{|l|}{$\mathrm{CO}_{2}$} \\
\hline & & t/year & $\mathrm{mg} / \mathrm{Nm}^{3}$ & kg/MWh & t/year & $\mathrm{g} / \mathrm{Nm}^{3}$ & $\mathrm{~kg} / \mathrm{MWh}$ \\
\hline$\overline{\mathrm{A} 3}$ & 668231 & 144 & 48.51 & 0.2 & 875420 & 260.2 & 1349 \\
\hline A4 & 879870 & 161 & 40.2 & 0.183 & 1169346 & 266.4 & 1341 \\
\hline A5 & 766707 & 139 & 37.52 & 0.177 & 1144104 & 266.2 & 1441 \\
\hline $\begin{array}{l}\Sigma / \text { Mon. } \\
\text { Average A }\end{array}$ & 2314809 & 444 & 42.53 & 0.187 & 3188870 & 264.2 & 1377 \\
\hline $\mathrm{B} 1$ & 1919950 & 3210 & 409 & 1.623 & 2099531 & 209.75 & 1089 \\
\hline $\mathrm{B} 2$ & 2014009 & 3254 & 375 & 1.593 & 2199983 & 201.52 & 1097 \\
\hline $\begin{array}{l}/ \text { Mon. } \\
\text { Average B }\end{array}$ & 3928071 & 6464 & 392 & 1.608 & 4299514 & 205.65 & 1093 \\
\hline
\end{tabular}

\section{RESUlts}

In January 2017, Prishtina has experienced again a heavy air pollution at a significant and very dangerous amount, according to the recent monitoring through AQI-Air Quality Index [12]. Moreover, the city of Prishtina has continuously raised values of air pollution in winter season every year, in the last decades. Nevertheless, the heavy worsening of the air quality has affected most citizens these days, thus public health deterioration continues to remain one of the vital worries of the households, as they are in constant worry for their children's health.

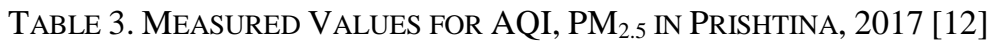

\begin{tabular}{llll}
\hline Per month, $\mathbf{P M}_{\mathbf{2 . 5}}$ & $\begin{array}{l}\text { The maximum value of } \\
\text { AQI }\end{array}$ & $\begin{array}{l}\text { The maximum amount } \\
\text { for an hour, } \boldsymbol{\mu} \mathbf{g} / \mathbf{m}^{\mathbf{3}}\end{array}$ & Date of maximum value \\
\hline January & 532 & 600 & 29.01 .2017 \\
February & 259 & 265 & 22.02 .2017 \\
March & 177 & 146 & 02.03 .2017 \\
April & 166 & 122 & 14.04 .2017 \\
May & 108 & 50 & 01.05 .2017 \\
June & 87 & 31 & 01.06 .2017 \\
July & 70 & 23 & 01.07 .2017 \\
August & 82 & 29 & 16.08 .2017 \\
September & 72 & 31 & 10.09 .2017 \\
October & 156 & 83 & 18.10 .2017 \\
November & 241 & 226 & 21.11 .2017 \\
December & 215 & 285 & 07.12 .2017 \\
\hline
\end{tabular}




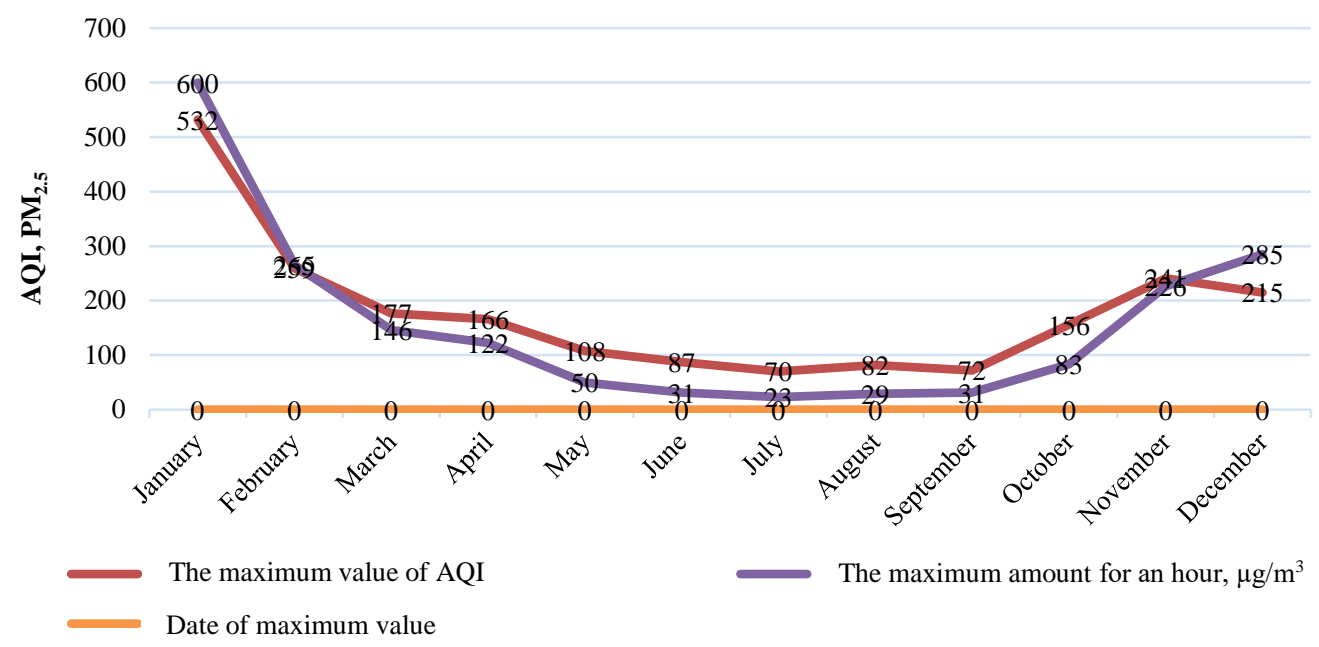

Fig. 2. Chart of measured values for AQI, $\mathrm{PM}_{2.5}$ in Prishtina, 2017.

Taken together, the most accurate way to solve a dilemma is to diagnose its source in the beginning, strengthened with the elimination method review in the case of air pollution, hence, it is of crucial importance to identify the major pollutants. Only after the largest pollutants have been identified, measures that will have an impact on reducing air pollution can be applied. In relation to the main pollutants, Power Plants Kosovo-A, and Kosovo-B, often categorized as the largest polluters in Kosovo, are the first to come to conclusion when it comes to air pollution.

The temperature inversion phenomenon plays a key role in creating smog and hold up pollutants in the atmosphere. As a consequence of this temperature inversion, pollutants are much more difficult to disperse into the atmosphere, especially for the city of Prishtina since its spatial morphology terrain is in the shape of a valley. This phenomenon occurs especially during cold periods, such as at night or during winter as presented in Fig. 4. Also, the lack of steady winds, rainfall, as presented in Fig. 3 and the presence of mountains around the settlement make the inversion stronger, and as a result the air quality is getting worse. Therefore, it is crucial that environmental pollution is the focus of priorities of central and local institutions. Factors affecting air, and water pollution in Prishtina are the energy industry, coal mining, industrial and urban dumpsites, and urban traffic. 


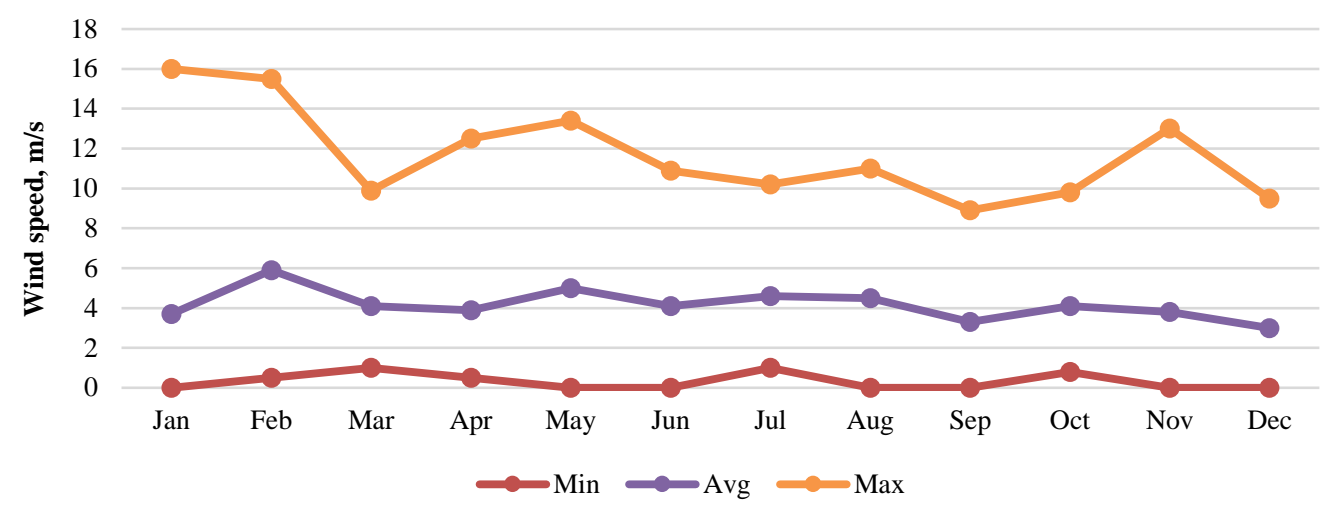

Fig. 3. Pristina. Max wind speed in Prishtina in 2016, $\mathrm{m} / \mathrm{s}$.

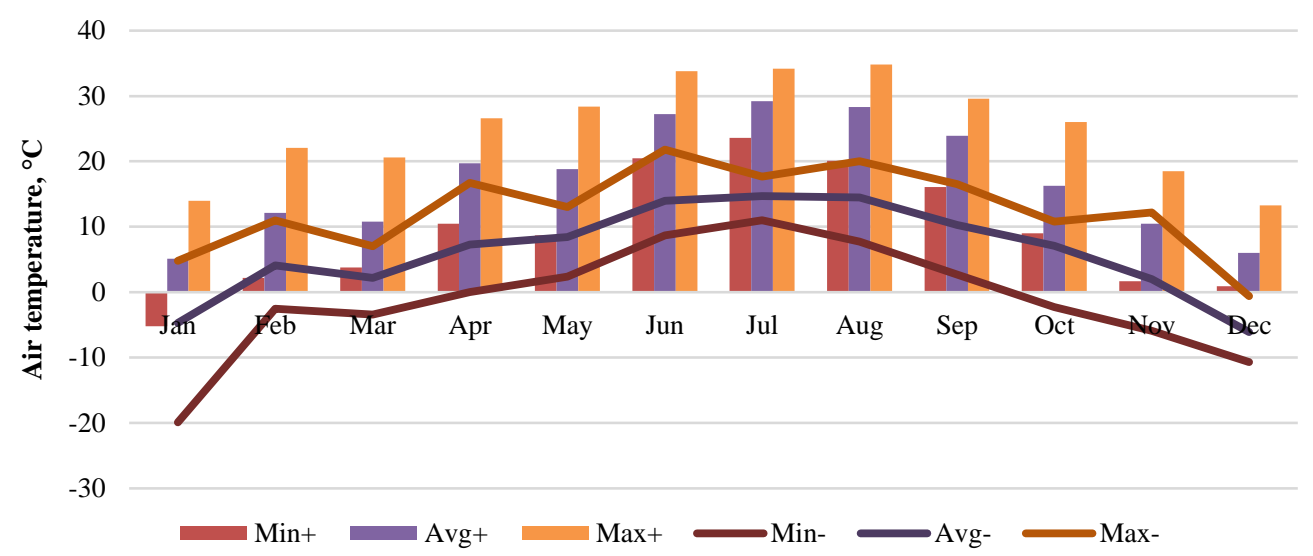

Fig. 4. Max and Min air temperature in Prishtina in $2016,{ }^{\circ} \mathrm{C}$.

\section{DiscuSsiON}

Data analysis of environmental impact of coal power plants, lead to the conceptual conclusion that every coal-fired Power Plant more or less permanently emanate harmful particles. This is an integrated process which is interdependent, and reciprocal with the operability of energy production. Evidently, as stated in the EU environment strategy, the enlarged amounts of coal for energy production will broadcast heavy extent of trace metals into the environment [3], [13]. Aerial particles, environment, and air quality are most essential features which need to be holistically answered [14]. With the Power Plant Kosovo-A that is heading towards the end of its operability, Kosovo is facing an energy crisis that will affect millions of citizens. In this context, Kosovo society is continuing its commitment for clean and sustainable power sources, and there are massive civil society debates on what is the best way to produce the so needed electricity. Is it to finance the renewable resources, which can fill the void in Kosovo, or is it lignite the only realistic option? When it comes to addressing the climate change and the use of fossil fuels, there is a fundamental concern that the world has not yet been able to overcome. Furthermore, it is the mayor agenda in every scientific debate, and is likely to be back in the global agenda at the 2019 UN Climate Change Conference, during 11-22 November 2019, location to be determined. Coal as the most 
polluting source of fossil fuels has a reasonable main burden with the largest number of calls for noninvestment's. In June 2013, the former U.S. President, Barack Obama stated: "the United States would stop investing in coal projects overseas, part of a broad package of climate measures, and called on multilateral banks to do the same" [15]. A month later the World Bank changed its coal policy, stating that it would support new coal projects 'only in rare circumstances' with tight criteria, allowing only coal investments to meet "energy needs in countries with no viable alternatives". For quite a time, the World Bank has considered whether the energy situation in Kosovo is one of those with 'rare circumstances' in which it will support the new coal-fired Power Plants. The prospective Kosovo-C Power Plant, currently is the only coal project in the development process, and will replace the old Power Plant Kosovo-A, which is regularly attributed as the largest carbon emission stamp in Europe. Kosovo is a small country, and power cuts are a regular manifestation, where the two-old coal-fired Power Plants, Kosovo-A and Kosovo-B, generate $98 \%$ of the country's power supply, using its brown coal reserves, which are the most polluting form of fossil fuel for generating the energy. When the Kosovo-A power plant closes, which will take place in 2020-2021, there will be a large capacity gap, which will disservice the energy sector, commercial, and ineffective billing system. Kosovo-C Power Plant has been proposed for more than a decade, but environmental struggle to build new lignite Power Plant, accompanied with a shortage of investors, brought a delayed outcome.

TABle 4. Ash Depot From Power Plants Kosovo-A AND B

\begin{tabular}{|c|c|c|c|c|c|c|}
\hline \multirow[t]{2}{*}{ Depot } & \multirow[t]{2}{*}{ Activity } & \multirow[t]{2}{*}{ Area } & \multirow[b]{2}{*}{$\begin{array}{l}\text { Annual } \\
\text { amount }\end{array}$} & \multirow[b]{2}{*}{ Volumes } & \multicolumn{2}{|c|}{ Potential sources of pollution } \\
\hline & & & & & $\begin{array}{l}\text { Chemical } \\
\text { substance }\end{array}$ & Oil Products \\
\hline $\begin{array}{l}\text { Ash depot } \\
\text { from } \\
\text { Kosovo-A } \\
\text { Power Plant }\end{array}$ & Ash Depot & 181.97 ha & $\begin{array}{l}0.87 \\
\text { mil.m³/year }\end{array}$ & 25 mil.m ${ }^{3}$ & $\sqrt{ }$ & $\sqrt{ }$ \\
\hline $\begin{array}{l}\text { Ash depot } \\
\text { from } \\
\text { Kosovo-B } \\
\text { Power Plant }\end{array}$ & Ash Depot & 192.94 ha & $\begin{array}{l}0.93 \\
\text { mil.m³/year }\end{array}$ & 14 mil.m ${ }^{3}$ & $\sqrt{ }$ & $\sqrt{ }$ \\
\hline $\begin{array}{l}\text { Reservoirs } \\
\text { with phenol, } \\
\text { Kosovo-A } \\
\text { Power Plant }\end{array}$ & $\begin{array}{l}\text { Reservoirs } \\
\text { with phenol, } \\
\text { Kosovo-A } \\
\text { Power Plant }\end{array}$ & 177.64 ha & & & $\sqrt{ }$ & $\sqrt{ }$ \\
\hline
\end{tabular}

In this situation, there is a certain belief that the expansion of the coal plan in Kosovo will be criticized by environmentalists. Brown coal is the most polluting form of fossil fuel in the world, and two lignite Power Plants in the Prishtina region, are the main contributors to more than 800 deaths annually due to air pollution conditions [16]. This rate of health hazard that citizens will suffer is likely to continue in the near decades in Prishtina. The heavy environmental issues in relation to the air pollution, mainly come from: Power Plant Kosovo-A, Power Plant Kosovo-B, heavy traffic, and using coal as the energy source for heating in households, furthermore, issues on the urban design challenges, overall energy efficiency, and public health hazards [17]. Many non-government organizations, individuals, and environmentalists have the official stand that the clean energy investment in Kosovo "will be cheaper, cleaner, and will create more jobs than planned Kosovo-C coal-fired Power Plant", but frankly this alternative does not answer the critical supply problem for electricity in Kosovo. The World Bank has stated that there is a low potential for renewable energy in 
Kosovo, where a Hydro Power Plants, especially in Zhur could be built with a capacity of 300 MW production, but again, according to the World Bank it will operate with about $20 \%$ of its capacity. Furthermore, while solar energy is considered very expensive at the beginning, also in the reaching objectives, again, the European Commission has noted low potential of wind, and geothermal energy in Kosovo. Hence, large amounts of industrial bio-waste can be processed through gasification, thus, creating the capabilities to improve industrial processes. Hereafter, biomass and carbon contained waste recovery will have a confident impact on the human development [18].

\section{Conclusions}

Public quality health can't be achieved only regionally. Environmental actions are crucial, but again, only through overall activities we can await the needed outcome of improved urban health and environmental preservation. In this study, we contend that there is no substitute or recompense to the health, hence, the actual state of energy production is not the most effective pathway to the stability for basic load of energy [19], [20]. Based in the research data analysis of the environmental impact of coal power plants, the following crucial actions are needed:

- Shutting down the old and archaic Kosovo-A Power Plant;

- Installing the best-known contemporary filters for Kosovo-B Power Plant chimneys;

- Treating the ash dumps of Kosovo-A and B, Power Plants with the best proven to-day;

- environmental technology;

- Building the new coal-fired Power Plant, with contemporary environmental technology;

- Advocating, and encouraging to ban coal heating in residential sector, with strategy

- to help and co-finance those households from municipality;

- Advocating, encouraging, and spreading the heating pipe network from cogeneration.

The ongoing debates focused around environment tend to fail the essential need for supplying Kosovo with electricity, something for which power plants are suitable, and unfortunately with all our environmental stubborn beliefs, renewable sources such as sun and wind are not considered as energy sources in the present agenda for Kosovo. The present degraded level of air quality requires precise lawful steps and activities; therefore, the conceptual research findings recommend to promote and carry out the above stated solutions as we consider that those environmental steps must be taken immediately.

\section{REFERENCES}

[1] Krumins J., Yang Zh., Zhang Q., Yan M., Klavins M. A study of weathered coal spectroscopic properties. Energy Procedia 2017:128:51-58. doi:10.1016/j.egypro.2017.09.014

[2] Silinš K., Žandeckis A., Valtere S. Determination of Solid Particle Concentration at Coal Transshipment Site. Environmental and Climate Technologies 2010:3(3):97-101. doi:10.2478/v10145-009-0013-8

[3] Bajçinovci B. Environment Quality: Impact from Traffic, Power Plant and Land Morphology, a Case Study of Prishtina. Environmental and Climate Technologies 2017:19:65-74. doi:10.1515/rtuect-2017-0006

[4] World Health Organization. Ambient air pollution: A global assessment of exposure and burden of disease. Geneva: WHO, 2016.

[5] Lillywhite S., Kemp D., Sturman K. Mining, resettlement and lost livelihoods: Listening to the Voices of Resettled Communities in Mualadzi, Mozambique. 2015. International Mining for Development Centre. Melbourne: Oxfam, 2015.

[6] Hastorun S. The Mineral Industry of Kosovo. 2014 Minerals Yearbook [Online]. [Accessed 7.01.2017]. Available: https://minerals.usgs.gov/minerals/pubs/country/2014/myb3-2014-kv.pdf

[7] Van den Berg C., et al. World Bank. Kosovo, Country Environmental Analysis, Cost Assessment of Environmental Degradation, Institutional Review, and Public Environmental Expenditure Review [Online]. [Accessed 5.11.2017]. Available: http://siteresources.worldbank.org/INTKOSOVO/Resources/KosovoCEA.pdf 
[8] Liu F., et al. A comparison of the consumption and carbon emissions for different modes of transportation in open-cut coal mines. International Journal of Mining Science and Technology 2015:25:261-266. doi:10.1016/j.ijmst.2015.02.015

[9] Kittipongvises S., Chavalparit O., Sutthirat C. Greenhouse Gases and Energy Intensity of Granite Rock Mining Operations in Thailand: A Case of Industrial Rock-Construction. Environmental and Climate Technologies 2016:18:64-75. doi:10.1515/rtuect-2016-0014

[10] Asere L., Blumberga A. Government and municipality owned building energy efficiency system dynamics modelling. Energy Procedia 2015:72:180-187. doi:10.1016/j.egypro.2015.06.026

[11] Kosovo Energy Corporation. Environmental Report for 2016. Kosovo: KEK, 2016. (in Albanian)

[12] Environmental Protection Agency, EPA, AirNow US 2017. Air Quality Index [Online]. [Accessed 06.01.2019]. Available: https://airnow.gov/index.cfm?action=airnow.global_summary\#Kosovo\$Pristina

[13] Sabbioni E., Goetz L., Bignoli G. Health and environmental implications of trace metals released from coal-fired power plants: an assessment study of the situation in the European Community'. Science of the Total Environment 1984:40(1):141-154. doi:10.1016/0048-9697(84)90348-6

[14] David O., Valia M., Maiduc S. The impact of the mining activity on the economic sector, human health and environment. Hidraulica 2014:2:44-47.

[15] Yukhananov A., Volcovici V. World Bank to limit financing of coal-fired plants [Online]. [Accessed 6.01.2018]. Available: https://www.reuters.com/article/us-worldbank-climate-coal/world-bank-to-limit-financing-of-coal-firedplants-idUSBRE96F19U20130716

[16] Republic of Kosovo. National Audit Office. The level of air pollution in Pristina dangerous to the health of citizens [Online]. [Accessed 17.10.2017]. Available: http://www.kosid.org/news/96

[17] Bajcinovci B., Jerliu F. Achieving Energy Efficiency in Accordance with Bioclimatic Architecture Principles. Environmental and Climate Technologies 2016:18:54-63. doi:10.1515/rtuect-2016-0013

[18] Klavins M., Bisters V., Burlakovs J. Small Scale Gasification Application and Perspectives in Circular Economy. Environmental and Climate Technologies 2018:22:42-54. doi:10.2478/rtuect-2018-0003

[19] Bariss U., Bazbauers G., Blumberga A., Blumberga D. System Dynamics Modeling of Households' Electricity Consumption and Cost-Income Ratio: A Case Study of Latvia. Environmental and Climate Technologies 2017:20:36-50. doi:10.1515/rtuect-2017-0009

[20] Blumberga A., Timma L., Blumberga D. System Dynamic Model for the Accumulation of Renewable Electricity using Power-to-Gas and Power-to-Liquid Concepts. Environmental and Climate Technologies 2016:16:54-68. doi:10.1515/rtuect-2015-0012

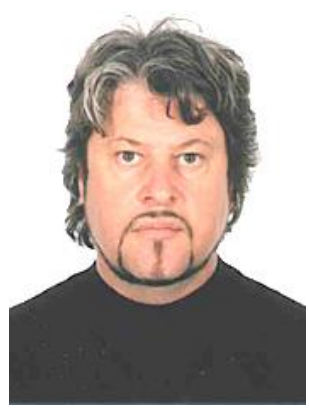

Bujar Bajcinovci received a Ph.D. grade on Technical Sciences in the field of architecture and urbanism from the Faculty of Architecture, University of Sarajevo, BiH (2012), and a Diploma in Architect Engineer from University of Prishtina (1991). He holds a position of assistant professor of the architectural design in University of Prishtina, Kosovo. He is an author of more than 7 scientific publications and conference papers indexed in SCOPUS and Web of Science, author of more than 40 scientific publications indexed in relevant scientific databases, a confirmed reviewer of 3 research papers (Publons), and author of 10 scientific monographs. Membership: International Academy of Sciences, Humanities and Arts. IASHA. Assistant editor of the Journal of Sciences, Humanities and Arts, JOSHA. Member of the Editorial Board of the Journal: Pollution Research. Member of the Editorial Board of the Journal: Ecology, Environment and Conservation.

ORCID ID: https://orcid.org/0000-0003-1494-6633 